\title{
ИННОВАЦИОННЫЕ ЛЕКАРСТВЕННЫЕ ФОРМЫ НА ОСНОВЕ ПЕКТИНОВЫХ ОЛИГОСАХАРИДОВ
}

\author{
Р.М. Горшкова ${ }^{1,2,3}$, Д.А. Слободова ${ }^{1,2,3}$, М.Н. Комбарова², С.А. Панков \\ 1НОЦ «Физхимбиофарм» Государственного университета «Дубна», \\ 141982, Россия, г. Дубна, ул. Университетская, 19. \\ 2000 «Мезон», 141982, Россия, г. Дубна, ул. Университетская, 19. \\ ЗСПбГУПТД, 191186, Санкт-Петербург, ул. Большая Морская, 18.
}

DOI: 10.19163/MedChemRussia2021-2021-142_E-mail:gorshkova.raisa@gmail.com

Пектиновые олигосахариды (ПОс) являются перспективными веществами из класса линейных биополимеров. Известно, что они положительно влияют на рост бифидо-и лакто-бактерий, сдерживая при этом развитие патогенов и вредных микроорганизмов. Малая размерность молекулы олигосахаридов обуславливает ряд уникальных свойств, полезных для медицины и фармацевтики.

Разработан способ получения высокоочищенных пектиновых олигосахаридов (арабинозы, галактозы, глюкозы, маннозы, галактозы и ксилозы) из промышленных сельскохозяйственных отходов методом комбинированного фракционирования в реакторе колонного типа. На их основе создан широкий спектр новых лекарственных форм (ЛФ) препаратов для перорального, внутримышечного и внутривенного применения, а также медицинских изделий.

Установлено, что включение ПОс в состав препаратов в жидкой ЛФ приводит к увеличению температурной разницы между максимальной скоростью критического зародышеобразования и линейной скоростью роста кристаллов, отвечающей за стеклование всей системы. Это обуславливает появление у лекарственной формы таких специальных свойств, как крио-и термоустойчивость, что позволяет избежать необходимости соблюдения жесткого температурного режима при хранении препаратов и дает возможность их применения при различных климатических условиях.

В условиях in vivo на мелких и крупных лабораторных животных проведены исследования эффективности и безопасности опытных серий препаратов с включением пектиновых олигосахаридов в качестве гастропротекторных, противовоспалительных, обезболивающих и кровевосполняющих средств. Выявлено, что между ПОс и действующими лекарственными веществами возникает эффект синергизма, усиливающий в 1,5-2 раза эффективность терапевтического действия и снижающий токсичность новых лекарственных форм по сравнению с традиционными ЛФ. 